\title{
TO TAKE ON THE NATURE OF WILD ANIMALS: ELEMENTS OF BIOLOGICAL HORROR IN THE FOURTH BRANCH OF THE MABINOGI
}

\section{ASSUMIR A FORMA DE ANIMAIS SELVAGENS: ELEMENTOS DE HORROR CORPORAL NO QUARTO RAMO DE MABINOGI}

\author{
Gabriela Pirotti Pereira \\ Universidade Federal do Rio Grande do Sul, Porto Alegre, Rio Grande do Sul, Brasil \\ gabrielapirottip@gmail.com
}

Albstract: Jason Colavito describes biological horror as a branch of horror fiction which deals with "uneasy feelings related to the physical body and its relationship with the natural world" (113). Those narratives often emerge during times in which there are social anxieties related to the unchecked expansion of science and the defiance of moral values is at play. In this article, I propose a reading of the tale of "Math, son of Mathonwy" which explores the possibility that this story depicts aspects of biological horror. By looking to the social and historical context of the medieval manuscript Y Mabinogi (The Mabinogi), this study goes over the scientific developments of twelfth-century Britain and correlates them to the instances of bodily transformation and physical punishment within the fourth branch of the Mabinogi. The analysis takes particular attention to the metamorphosis of the character Blodeuwedd, who is permanently altered in her physicality as judgment for her moral actions. Ultimately, the fluid nature of bodies within the tale does depict some aspects of biological horror which seem to echo some of the questions which monastic scholarly introduced during the Middle Ages.

Keywords: Body Horror; Blodeuwedd; Medieval Science; Welsh Literature

Resumo: Jason Colavito (2007) descreve "horror corporal" como uma seção na ficção de horror que se ocupa das "inquietações relacionadas ao corpo físico e seu relacionamento com o mundo natural" (p. 113). Tais narrativas frequentemente emergem durante períodos nos quais há ansiedades sociais conectadas à expansão científica e algum desafio aos valores morais. $\mathrm{O}$ presente artigo propõe uma leitura da história "Math, son of Mathonwy" explorando a possibilidade de que esta narrativa apresenta aspectos de horror corporal. Olhando para o contexto histórico e social do manuscrito medieval Y Mabinogi (O Mabinogi), este estudo revisa os debates científicos que ocorreram na Grã-Bretanha durante o século XII, e os relaciona com as transformações corporais e punição física apresentadas no quarto ramo do Mabinogi. Esta análise foca principalmente na metamorfose da personagem Blodeuwedd, cujo corpo é permanentemente alterado como parte de um julgamento por suas ações morais. Por fim, a natureza fluida dos corpos nesta narrativa demonstra alguma semelhança com o horror corporal, por se aproximar de alguns dos debates e questionamentos introduzidos pelos estudos monásticos durante a Idade Média.

Palavras-chave: Body horror; Blodeuwedd; Ciência medieval; Literatura galesa

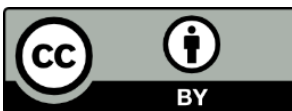


The fourth branch of the Mabinogi features several instances of bodily transformation - all of them arguably horrifying, as they violate and pervert the boundaries of an individual's physiology. The present article intends to analyze these metamorphoses as depicting some aspects of biological horror. Other authors have already hinted to the monstrous nature of the transformations which the Mabinogion's ${ }^{1}$ characters suffer; however, it seems scholars have yet to examine the metamorphoses featured within these tales in relation to the turbulent social background of their writing. In light of that, I intend to associate the contents of the fourth branch of the Mabinogi to the scientific and philosophical developments which took place in the twelfth century, thus linking it to the concept of biological horror.

Jason Colavito looks to horror motifs in correlation to the social and historical context those themes first appeared, or the times in which they have been revisited in fiction. The author explains the emergence of iconic horror figures like Frankenstein's creature, Dr. Jekyll and Hyde, and Dracula, by linking them to anxieties brought on by the nineteenth century's technological discoveries (Colavito). Throughout this analysis, I seek to look at the transformations in the fourth branch of the Mabinogi - paying particular mind to Blodeuedd's - under a similar light. By revisiting the social and scientific upheaval during the time period scholars have named the "Medieval Renaissance", this article aims to identify and debate elements of biological horror in the tale of Math, son of Mathonwy.

Before plunging into this study, I must make some notes concerning the Mabinogi: its tales are ancient. They were originally developed in early medieval oral Welsh literature, then transcribed into manuscripts by Christian monks, and finally translated into English during the nineteenth century. It is hardly possible to exact at which point, if at all, they have been changed over time in oral literature, or even if there were any alterations to the stories when they were first transcribed. Therefore, the present analysis will look at the Mabinogi as they were put into writing, considering much of its aspects might reflect fears that people in the High Middle Ages may have experienced. Although these stories date from an even earlier time (Lupack) and circulated mainly among people who would almost certainly not be inserted in the monastic debates, I argue that what these tales display - and its cultural relevance - was considered an important subject at the time of their writing, for the people writing them, precisely because new philosophical ideas were on the rise and, along with them, uncertainty and fear. Therefore, I understand that looking at the metamorphoses this text presents in relation to the social anxieties that have assailed Europe in the Middle Ages is a viable line of thought, and that it can be understood as a form of biological horror. Throughout this article, I will reference Sioned Davies' even more contemporary translation (published in 2007), considering it does retain a core element from the medieval version - a horrible bodily transformation -, which is the main object to this study.

The Mabinogion are nineteenth-century translations of the medieval Welsh manuscripts Llyfr Coch Hergest (The Red Book of Hergest) and Llyfr Gwyn Rhydderch (The White Book of Rhydderch). They were possibly written between the eleventh and the fourteenth centuries, in a wide time frame during which Wales was in constant clash with invading AngloNorman forces; that conflict "ultimately transformed the society, economy, and church of Wales" (Davies xviii). As a response to the colonization process imposed upon them, the Welsh developed a strong sense of community. Through language and literature, the people within that

\footnotetext{
${ }^{1}$ The term mabinogion gained traction with Charlotte Guest's translation; it was originally a scribal error for mabinogi, as the suffix -(i) on is a common plural ending in Welsh. (Davies ix)
} 
region began referring to themselves as a unity: they were the Cymry, meaning "fellow countrymen" (Fear 46-47) and thus created an identity in opposition to that of the invaders.

The work is composed of eleven tales; four of those are distinctively grouped into what scholars consider to be "branches" due to their all ending with the similar line of "and so ends this branch of the Mabinogi" (Davies x). Throughout these tales, the only recurrent character is Pryderi, a prince and warrior; other figures often possess supernatural powers. That is particularly relevant to the fourth branch of the Mabinogi, as the character who gives this section its title - Math son of Mathonwy - has a magical rod which grants him the ability of mutating others' bodies at will. According to the story, Math was the lord of Gwynedd, one of the four Welsh independent kingdoms, who could not live without resting his feet on the lap of a virgin, unless he was at war; Goewin was the woman to play that role, and kept the ruler constant company. Gilfaethwy and Gwydion, Math's nephews, plotted to get the lord and Goewin apart by arranging a war with the kingdom of Powys. Gilfaethwy was said to have fallen madly in love with the maiden, and with the help of his brother, assaults her when Math is away.

Once the lord learns of what happened, he punishes his nephews by turning them both into animals with his magical rod, one male and one female, so they would produce offspring by each other, declaring that they would "take on the nature of the wild animals" (The Mabinogion 52-53) whose shape they assume; the brothers undergo this process three times before they are allowed to come back to court. As Math now needs to find another maiden to hold his feet he, again with his magical rod, tests a woman named Aranrhod by having her pass over his bent wand. When Aranrhod takes a step over the rod, she instantly births a full-term infant, which would prove she was not a virgin; as she runs out of the room, she drops another baby, this time not fully formed, who Gwydion wraps in silk and hides in a chest.

That baby grows up to be Lleu Llaw Gyffes: he is cursed by Aranrhod - who could not stand the shame of bearing that child - to never have a name, weapons, or a wife. Gwydion, by trickery and shape-shifting, grants Lleu all of those. At this point, Bloddeuedd enters the story; Math and Gwydion join their magic to shape a woman out of "the flowers of the oak, and the flowers of the broom, and the flowers of the meadowsweet" (The Mabinogion 58) so she could be Lleu's wife. After their marriage, Lleu goes away to visit Math. In that time Bloddeuedd meets a lord named Gronw and they soon become lovers; together, they plot to murder Lleu, but are discovered. Gronw is killed, and Gwydion punishes Bloddeuedd for her adultery and betrayal by turning her into an owl, and henceforth she is known as Blodeuwedd. As Lleu reestablishes his rule and subdues those who threatened it, the tales end. Upon turning the woman made of flowers into a bird, Gwydion makes a statement about her fate, making it clear the scorn which would forever be directed towards her, as she held the shape of a nocturnal bird:

\footnotetext{
And because of the shame you have brought upon Lleu Llaw Gyffes, you will never dare show your face in daylight for fear of all the birds. And all the birds will be hostile towards you. And it shall be in their nature to strike you and molest you wherever they find you. You shall not lose your name, however, but shall always be called Blodeuwedd. (The Mabinogion 63)
}

Colavito's definition of biological horror (also called body horror) is "horror directed towards the physical being of the protagonist and the supernatural entity" (78). This type of narrative often portrays creatures which are both human and some sort of beast - an attempt at reconciliation of "mankind" with the "natural world". At the heart of biological horror is the 
binary notion of civilization $v s$. savagery, and how the first could easily dissolve into the latter. Another prevalent aspect in these narratives is the dangers of knowledge; overreaching ambitions, learning some forbidden art - and at times, willful ignorance - are often the cause for a character's downfall.

The author correlates the dawn of biological horror to the scientific developments of nineteenth century England. As the evolutionary theories - along with medical studies - became more widespread, there was an increasing fear of the consequences that these discoveries could bring. From a moral and theological standpoint, defying the creationist view would imply that humans were no ultimate, perfect creation of God - instead, they were animals as much as any other natural beast. It proved an uncomfortable notion to the Victorian society, that which deemed humanity capable of savagery. It confronted people with the notion that the "civilized" man was constantly on the edge of giving in to base animal instincts, which only gained traction as a variety of serial killers emerged towards the end of the century (Colavito). In regards to the rise of violence during the nineteenth century, the author describes:

\begin{abstract}
Across the nineteenth century landscape, the paradox of progress led to a schizophrenic century, one simultaneously defined by progress and by brutality, by science and by savagery. It is therefore unsurprising that this period created the horror fiction icons that ever after defined the genre (...). These horror figures attempted to bridge the contradictory impulses of the society in which they were formed, and they attempted to navigate the shifting boundaries between humanity's traditional role as separate from and ruling over nature with its new position as merely one part of a bloody, violent world of competition, exploitation, and fear (Colavito 77).
\end{abstract}

In light of that, one can affirm that social and scientific change is often met with anxiety; fear arises, as where there is "progress" there are also horrors lurking about. As previously mentioned, the Mabinogion were transcribed at some point during the High Middle Ages, within a context of political clashes, cultural turmoil, and a blossoming intellectual scene. In 1927, historian Charles H. Haskins devoted his work to what he identified as "the renaissance of the twelfth century". Haskins' analysis seeks to point out the many cultural developments which took place during such time-frame, being one of the first to contradict the idea of the "Dark Ages", which portrayed the medieval era as centuries of ignorance and stagnation. The author understands that there is continuity to history, meaning that the more widely known Italian Renaissance only became possible because medieval scholarly had laid the path for the scientific discoveries and cultural expansion to come. According to Haskins (b), the Middle Ages witnessed a vast search for knowledge, novelty in the arts and literature, as well as philosophical and political debates. Among the scientific accomplishments of the twelfth century were the translation of Greek, Latin, and Arabic texts, the beginning of vernacular literature, development of Romanesque art and Gothic architecture, and the origins of European universities.

Robert Benson et al. expand on Haskins' studies, delving deeper into the intellectual production of the twelfth century and its cultural impact. They also develop on the notion of a "twelfth-century renaissance", and give the concept a clearer outline demonstrating that the epoch's strongest feature "was the consciousness of its position in history, its sense of time and of times, of change and innovation" (Benson et al xxv). For instance, in describing the work of Bernard Silvester, medieval poet and scholar, the authors display the extensive discussion on cosmography - or the matter of creation - which emerged during the "Medieval Renaissance". The study of the cosmos consisted on the search for understanding the macrocosmos - space, 
the stars, astrology, and celestial bodies - and the microcosmos - the study of the human body itself (Hannan). When explaining Bernard Silvester's line of thought, the authors state that creation was considered to be a product of desire - the wish of chaotic matter to take on different shapes, and it "envisages periodic renewals of the universe and of man: everything that exists in time was first born in eternity and will return to it, only to be born again" (Benson et al 6). Concerning the elements of matter and nature, the aforementioned authors stress that,

In twelfth-century terminology and ideology the word nasci, with which natura is often closely linked, is more important than the term renasci, and the terminology of nature, birth, and growth represents one of the most characteristic aspects of the twelfth-century renaissance (Benson et al 10).

Creation, renewal and re-forming, then, were key concepts to the twelfth century scholarly. While authors like Bernard Silvester approached creation in a material sense by personifying nature, others like St. Bernard of Clairvaux and Anselm of Canterbury would understand the re-formation of man as a mystical force which could bring him to divine grace, and so, closer to the likeness of God. What can be concluded is that there were seemingly contradictory stances on the same subject, and creation was sometimes viewed as natural, and other times as supranatural; both were, nevertheless, pervaded by Christian spirituality (Benson et al). The revival of Aristotle's studies on physics and the natural realm originated comparisons between human and animal nature, "discussing intelligence, free will, and the senses" (Haskins (a)).

Within the fourth branch of the Mabinogi, in particular, bodies are mutable and ambiguous as they change size, shape, and sex - and often engage in taboo sexual acts. Those, nevertheless, are very much connected to birth, renewal and creation, which are arguably the tale's main themes. That is made clear by the prevalence of giving birth and procreating, which is represented by Gilfaethwy and Gwydion human offspring, and by Aranrhod. Sarah Sheehan analyses those aspects in the tale of Math son of Mathonwy under the light of gender and psychoanalytical theories and notes:

Characters both female and male lack control over their bodies, which become subject to compulsion or violation: a virgin is raped; a woman is forced to give birth in public; two brothers must engage in incestuous, procreative sex. Phallic symbols do not function quite as we might expect, and the text's depictions of female anatomy and childbirth are hard to decipher (Sheehan 319).

Sheehan points out the linguistic ambiguities within the Welsh text, which allow for a reading that, in order to survive, Math would have to keep his feet in the womb of a virgin rather than "lap", as it is often translated - which may recall the importance of growth and reproduction. The author also makes remarks about Aranrhod's public parturition; first, an infant is born, but the second child is described as a "kind of little thing (ryw bethan), which, as we can infer from later narrative developments, is an embryo" (Sheehan 325). Not only does this imply a kind of abortion, the following segment shows how Gwydion hides the "little thing" in a chest and brings it to what Sheehan describes as an "extrauterine birth" (326). Finally, Bloddeudd's origins are completely detached from any form of human procreation, as Math and Gwyidion form her out of flowers. Sheehan also declares that the punished brothers' essence would have been completely unaffected by their shape-shifting, and thus, the fact that they were originally male humans who gave birth to one another's offspring would not present a source of horror to Welsh audiences. All those depictions of "unnatural" births seem to 
explore and experiment with the limits of creation, while echoing the twelfth century inquiries over change, renewal and rebirth.

Roughly around the same time as the debate over cosmography gained traction, Hildegard of Bingen wrote treaties on medicine directly linking bodily humors and "temperaments of the soul" to moral agency. By altering certain fluids of a person's body, she stated, they could be more inclined towards virtuous action; the ethical "soul" and physiology appear inextricably joined within Hildegard's work and again those are connected to nature as she compares repentance and penance to "greening and regreening of the life of man" (Benson et al 17). Those ideas derived from Greek theories on the elements of hot, cold, wet and dry. That discussion is particularly relevant in regards to Bloddeuedd's transformation; while Gilfaethwy and Gwydion regain their human bodies and are redeemed by the end of their punishment, Blodeuwedd is permanently changed - and thus, never forgiven by her moral shortcomings. The consequences of her punishment are marked within the character's name, demonstrating that the alterations of her body result in a change of essence:

This metamorphosis worse than death prescribes banishment from daylight and ostracism in the shape of a bird, the owl; for a Welsh audience, the similarity of blodeu-edd (flowers-es, a double plural) to blodeu-wedd (flower face) may have marked the flower woman as always already punished (Sheehan 334).

And as such, the fate of Blodeuwedd warns against the subversion of the social order. As a whole, the fourth branch' central point is "the violation of a status quo caused either by adultery, overlapping of the sacred and the profane, interference with nature and the otherworld" (Bednarski 239). Davies argues that the Mabinogi tales imply certain moral lessons concerning social values and the norms of the newly established feudal system, while also never making any direct commentary and leaving the readers to draw their own conclusions (xxiv). When it comes to Blodeuwedd's role,

She is human but, being an aberration of natural order and a simulacrum, she also transgresses human moral norms. As the product of "magical" experimentation, despite her beauty, Blodeuwedd can also be seen as inscribed in the modern tendency to explore the motif of artificially created anthropomorphic beings like Frankenstein's monster or, more recently, robots endowed with artificial intelligence (Bednarski 243244).

The comparison to Frankenstein's creature clearly points to Blodeuwedd's monstrosity, as she is a liminal and ambiguous figure, which is what Aleksander Bednarski argues throughout his study. Her lack of identity, or rather, her overlapping of boundaries and fluid form, strongly speak of an anxiety over "being", and an exploration of the concept of "self". Arguably, one of the most relevant notions to emerge in the twelfth century's burst of scholarly is a conception of the "inner-self", which evolved into an early notion individuality; developed mainly through the renewal of religious views in this "new age" and through a deeper practice of self-examination (Benson et al), that concept would soon become subject of other cultural manifestations,

They [religious thinkers] contributed to the growing sense of individualism, or of individuation, both of people and of groups, which was founded on an examination of the inner life and awareness of self; they contributed also to the emerging doctrine of the dignity of man, based far more on religious then on secular sources and attitudes. 
The concept of experience, conscience, and virtue were the discoveries of the twelfthcentury renaissance no less than of the later Italian Renaissance (Benson et al xxiii).

In refining language to refer to the internal life of a person, twelfth century renaissance encouraged a clearer awareness of the "self" in relation to previous philosophical discussions. It is by no means the definition of "personality" which was conceived in the nineteenth century and developed from then onwards, but it presented a significant and unprecedented change in thought. The metamorphoses presented in fourth branch of the Mabinogi often have a strong implication to a character's being. Sheehan demonstrates that both body and name are strongly tied to the sense of identity within the Mabinogion, which makes Blodeuwedd's transformation unique.

Bednarski concisely describes how scholarly has established Blodeuwedd as a frontier figure: as a woman made of flowers, she dwells between the vegetable and the animal realms. Her later transformation into an owl further reinforces that role, as she turns from woman to beast, and such association with the owl also places Blodeuwedd on the boundary between life and death (Bednarski). The author remarks that Blodeuwedd's moral and sexual transgression is yet another form of ambiguity to her character;

\begin{abstract}
Another important point is that the ambivalence inherent in the fourth branch is also transferred to the linguistic level of the narrative. In the tale, the name of Lleu's wife has two forms: Blodeuedd ("flowers") and Blodeuwedd ("flower face") after her transformation into an owl. The latter name, as declared by Gwydion and confirmed by the narrator, from then on has been used to refer to the nocturnal bird. Thus, an additional layer of ambiguity is added to the picture as the transformation in body is followed by a shift in language (Bednarski 239).
\end{abstract}

Shape shifting, or losing control over one's body, is often portrayed as punishment for defying a lord's authority. The association between an unchangeable, wholesome body and power is consistent within narratives of body horror, as "in order for the body to represent the symbolic order it must be unmarked" (Creed 47). The Mabinogion, then, display a certain set of values which should be conveyed to society - but even when portraying punishment, these tales put emphasis on reconciliation and forgiveness, as "the image of a man alone, at the end of the Fourth Branch, with no wife and no heir, does not make for a promising future" (Davies xxvi). The nature and impact of such punishment is not the same to every character, though. Gilfaethwy and Gwydion are never called by their own names when in animal shape, and eventually regain their bodies, and "the text's unexpected lack of discomfort with its queerly engendered births suggests that the transformed brothers should be regarded as having completely lost their human gendered identity" (Sheehan 332). Alternatively, Blodeuwedd's transformation proves to be permanent precisely because her name has been irrevocably changed (Sheehan).

The emphasis given to names clearly demonstrates a deep concern with outlining identity, be that of an individual or a group. That would have been a relevant topic of debate to European scholarly during the twelfth century; then, the nearby threat of the "Other" was a constant issue which took on the shape of foreign science, as "in the time of the Crusades, knowledge which came from the pagan past via the Saracens was doubly troubling, and had to be handled with extreme care" (Lawrence-Mathers 103). The matter of "identity" would be rather urgent within Britain, and especially to the Welsh, considering that the Norman expansion over Wales was at full force, and feudalism was forcibly established as the ruling 
system. It could be argued that the wars and violence which occurred during that period forced those concepts to be developed, and jumpstarted early notions of a distinct cultural identity. When it comes to the social and political atmosphere of Wales during the twelfth century, it is relevant to remark that:

As a linguistically and culturally distinct population within Britain, the medieval Welsh occupied a marginal position in relation to those who shaped the political and intellectual climate of the period; in the later Middle Ages, the Anglo-Normans constructed the Welsh as colonial others partly by exploiting Welsh cultural difference (Sheehan 320).

In some ways, that political environment recalls Colavito's description of the nineteenth century; at that time, European colonialist expansion and racism were on the rise, and Darwin's evolutionary theory was twisted in order to justify those actions, as "early supporters of evolution attempted to classify human beings by race, assigning each a slot on the developmental scale" (Colavito 77). The twelfth century brought about the Anglo-Norman invasion in Britain, as well as the expansion of the Crusades; even though the latter is not connected to the wave of translations of Arabic texts, there were certain boundaries which separated the acceptable sciences from the perceived dark and strange arts which should not be touched. Astrology was considered a part of the latter, as an ambiguous line study which could be good when used as a means of understanding the signals and movements of the universe, but heretic when done as a means of predicting the future.

Even texts which were translated from Greek and Latin - often studies on what was called "natural philosophy" - were at times viewed with some suspicion, as "from the early Middle Ages, the Catholic Church was divided as to the extent to which pagan literature could or should be studied" (Deming 123). Moreover, even that knowledge which might not have been condemned by the religious doctrine of the time presented some sort of novelty, and thus evoked a certain amount of intellectual exploration, if not some level of discomfort.

By going over those aspects and briefly relating them to the Mabinogi's context of production, this article has intended to point elements of biological horror in the tale of Math, son of Mathowny. The twelfth century renaissance in Britain was a period of both blossoming intellectuality and of vicious war and oppression. In some ways, this turbulent environment proves similar to that of the nineteenth century Europe - with scientific developments, moral and philosophical inquiries, imperialism and colonization. The Mabinogi, as a work originated by Welsh oral literature, was not directly aligned with the Christian, aristocratic scholarly even still, it is through those registers that these tales have eventually reached English literature, and as both traditions interact, they are inevitably influenced by one another.

The fourth branch of the Mabinogi displays all sorts of bodily transformations, which more often than not consist of punishment through the violation of a character's physiology. Those metamorphoses appear to echo some of the questions which monastic scholarly introduced: the great interest in birth, growth, and creation in general is addressed by the diverse and unusual parturitions within the story. Bodies are also related to authority, which is a relevant issue to the medieval society as the feudal system settled - and lack of control over one's physicality is used multiple times as a punishment for defying said authority. A strong sense of "identity" would have been important both to the Normans, as they implemented feudalism and dominated Britain, and to the Welsh, who attempted to resist that and maintain their own culture. Therefore, power is related to the dominium of one's form. The permanence of names 
is connected to an early notion of individual identity, as the physical transformations the characters undergo might be reversed as long as their name remains unchanged.

There is much to be said about the interest in corporeal physiology within the Mabinogi, particularly when analyzing the figure of Blodeuwedd. Her creation is wholly unnatural: she is magically formed out of flowers, and only meant to become Lleu Llaw Gyffes' wife. Once she deviates from such purpose, and along with her lover attempts to murder Lleu, her form is again twisted, this time, into an owl. There is no permanence to her shape, and she is made totally powerless before the magic of Gwydion and Math. As her moral stance is presented as ambiguous, so is the fluidity of her body, and her fate is ultimately defined by her physical form. Thus, the metamorphoses Blodeuwedd magically undergoes throughout the fourth branch connect this character to the revival of Greek philosophy and to the recent developments about the physical matter of the world by evoking the problem of creation. As she is molded out of flowers into the shape of a human woman, then turned into a night bird, Blodeuwedd is deeply linked to nature, the macrocosmos, which then forms her body, a mutable microcosm.

The two main aspects of a narrative of biological horror, as Colavito describes, are the overreaching plot, the discovery plot, and the text's links to social anxieties concerning the unchecked expansion of science and defiance of moral values. Though the search for knowledge is not depicted within the story of the fourth branch as a source of horror, the fear of scientific and philosophical discoveries which happened as the Mabinogi was being written is weaved through its plot and characters. The overreacher plot is somewhat present through Blodeuwedd's transgressions, as she aspires to break the established social order and rise above it. There are a few aspects within this narrative which are meant to evoke fear - punishments and tests that bring great shame to those who experience them - that are directly related to the violation of the boundaries of one's body; the story is populated by hybrids and mutations, and those are linked to a set of moral values implied by the narrative. It serves, in its own way, as a cautionary tale which is relevant to its time: a body which is whole and incorruptible stands as a similarly resilient, moral, character.

\section{References}

Bednarski, Aleksander. "A Hybrid made of Flowers: Blodeuwedd in Gwyneth Lewis's 'The Meat Tree'". In: BAńKA, Ewelina et al (ed.). Borderlands: Art, Literature, Culture, edited by Ewelina Banka, Wydawnictwo Kul, 2016, pp. 235-252.

Benson, Robert L et al, editors. Renaissance and Renewal in the Twelfth Century, Toronto, University of Toronto Press, 1999.

Colavito, Jason. Knowing Fear: Science, Knowledge and the Development of the Horror Genre, Jefferson, McFarland \& Company, 2007.

Creed, Barbara. The Monstrous-Feminine: Film, Feminism, Psychoanalysis, New York, Routledge, 2007.

Davies, Sioned. "Introduction”. The Mabinogion, Oxford, Oxford University Press, 2007. 
Deming, David. Science and technology in world history, Jefferson, McFarland \& Company, 2010.

Fear, Alan P. A Search for Identity and Memory in Sharon Kay Penman's Novel Here be Dragons. 2016. Universidade Federal do Rio Grande do Sul, PhD Dissertation.

Haskins, Charles H. (a). Studies in the History of Mediaeval Science, Cambridge, Harvard University Press, 1924.

--- (b). The Renaissance of the Twelfth Century, Cambridge, Harvard University Press, 1927.

Hannam, James. The Genesis of Science: How the Christian Middle Ages lauched the scientific revolution, Washington, Regnery Publishing, Inc., 2011.

Lawrence-Mathers, Anne. The True Story of Merlin the Magician, Padstow, Yale University Press, 2012.

Lupack, Alan. The Oxford Guide to Arthurian Literature and Legend, Oxford, Oxford University Press, 2007.

Sheehan, Sarah. "Matrilineal Subjects: Ambiguity, Bodies, and Metamorphosis in the Fourth Branch of the Mabinogi". Signs: Journal of Women in Culture and Society, vol. 34, no. 2, 2009, pp. 319-342. doi: 10.1086/591089.

The Mabinogion. Translated by: Sioned Davies, Oxford, Oxford University Press, 2007.

Recebido em: 01 de agosto de 2020 Aceito em: 09 de outubro de 2020 Publicado em dezembro de 2020 